Article

\title{
Effect of Mn and Fe on the Formation of Fe- and Mn-Rich Intermetallics in Al-5Mg-Mn Alloys Solidified Under Near-Rapid Cooling
}

\author{
Yulin Liu *, Gaoren Huang, Yimeng Sun, Li Zhang, Zhenwei Huang, Jijie Wang \\ and Chunzhong Liu
}

Liaoning Provincial Key Laboratory of Light Alloys and Processing Technology,

School of Materials Science and Engineering, Shenyang Aerospace University, Shenyang 110136, China;

grhuang2014@sina.com (G.H.); ymengsun@sina.com (Y.S.); zhangli@sau.edu.cn (L.Z.);

zwhuang@sau.edu.cn (Z.H.); wangjijie@sau.edu.cn (J.W.); czliu@sau.edu.cn (C.L.)

* Correspondence: ylliu@sau.edu.cn; Tel.: +86-133-5243-6226

Academic Editor: Douglas Ivey

Received: 27 December 2015; Accepted: 25 January 2016; Published: 29 January 2016

\begin{abstract}
Mn was an important alloying element used in $\mathrm{Al}-\mathrm{Mg}-\mathrm{Mn}$ alloys. However, it had to be limited to a low level $(<1.0 \mathrm{wt} \%)$ to avoid the formation of coarse intermetallics. In order to take full advantage of the benefits of $\mathrm{Mn}$, research was carried out to investigate the possibility of increasing the content of Mn by studying the effect of cooling rate on the formation of Feand Mn-rich intermetallics at different content levels of $\mathrm{Mn}$ and Fe. The results indicated that in $\mathrm{Al}-5 \mathrm{Mg}-\mathrm{Mn}$ alloy with low Fe content $(<0.1 \mathrm{wt} \%)$, intermetallic $\mathrm{Al}_{6}(\mathrm{Fe}, \mathrm{Mn})$ was small in size and amount. With increasing Mn content, intermetallic $\mathrm{Al}_{6}(\mathrm{Fe}, \mathrm{Mn})$ increased, but in limited amount. In high-Fe-containing $\mathrm{Al}-5 \mathrm{Mg}-\mathrm{Mn}$ alloys $(0.5 \mathrm{wt} \% \mathrm{Fe})$, intermetallic $\mathrm{Al}_{6}(\mathrm{Fe}, \mathrm{Mn})$ became the dominant phase, even in the alloy with low Mn content $(0.39 \mathrm{wt} \%)$. Cooling rate played a critical role in the refinement of the intermetallics. Under near-rapid cooling, intermetallic $\mathrm{Al}_{6}(\mathrm{Fe}, \mathrm{Mn})$ was extremely refined. Even in the high $\mathrm{Mn}$ and/or high-Fe-containing alloys, it still demonstrated fine Chinese script structures. However, once the alloy composition passed beyond the eutectic point, the primary intermetallic $\mathrm{Al}_{6}(\mathrm{Fe}, \mathrm{Mn})$ phase displayed extremely coarse platelet-like morphology. Increasing the content of Fe caused intermetallic $\mathrm{Al}_{6}(\mathrm{Fe}, \mathrm{Mn})$ to become the primary phase at a lower Mn content.
\end{abstract}

Keywords: aluminum alloy; intermetallics; phase transformation; casting; rapid solidification

\section{Introduction}

Al-Mg-Mn alloys AA5182 and AA5083 have found great applications in the automotive, marine, packaging, and construction industries due to their special characteristics, such as good weldability, ductility, toughness, formability, and corrosion resistance. In Al-Mg based alloys, Fe was the main impurity and formed the Fe-rich intermetallic, $\mathrm{Al}_{3} \mathrm{Fe}$, in needle-like form [1]. This type of intermetallic has been considered most detrimental to the mechanical properties of the alloy, due to its brittle features and stress concentration caused by the needle-like morphology [2-4]. Fe was also considered a detrimental element in corrosion resistance [5,6]. Mn had usually been added to Al-Mg-based alloys to compensate for the negative effects of the Fe-rich intermetallic $\mathrm{Al}_{3} \mathrm{Fe}$. The addition of $\mathrm{Mn}$ to the alloy transformed the $\mathrm{Al}_{3} \mathrm{Fe}$ phase to the $\mathrm{Al}_{6}(\mathrm{Fe}, \mathrm{Mn})$ phase, and the needle-like morphology of $\mathrm{Al}_{3} \mathrm{Fe}$ to the Chinese script morphology of $\mathrm{Al}_{6}(\mathrm{Fe}, \mathrm{Mn})[7,8]$. It was thought that intermetallics with Chinese script morphology would have less harmful effects on the mechanical properties of the alloy. In addition, $\mathrm{Mn}$, through solid solution strengthening, could increase the strength of the alloy. Thus, increasing the content of Mn could also increase the strength of the alloy. For example, increasing Mn from 
$0.35 \mathrm{wt} \%$ in the AA5182 alloy to $0.7 \mathrm{wt} \%$ in the AA5083 alloy resulted in the increase of tensile strength by $15 \mathrm{MPa}$ at $\mathrm{O}$ temper [9]. Therefore, a higher content of $\mathrm{Mn}$ favored the strength of the alloy.

On the other hand, with the increase of $\mathrm{Mn}$ content, intermetallic $\mathrm{Al}_{6}(\mathrm{Fe}, \mathrm{Mn})$ would also increase in both size and amount. The coarse $\mathrm{Al}_{6}(\mathrm{Fe}, \mathrm{Mn})$ would significantly deteriorate the mechanical properties of the alloy. As a result, increasing the content of Mn affected the alloy in two aspects: increasing its strength due to the increase of $\mathrm{Mn}$ atoms in solid solution, and decreasing its strength due to the increase of intermetallic $\mathrm{Al}_{6}(\mathrm{Fe}, \mathrm{Mn})$ in both size and amount. In order to balance the positive and negative effects of $\mathrm{Mn}$, the content of $\mathrm{Mn}$ had to be limited to a low level to control the size and amount of intermetallic $\mathrm{Al}_{6}(\mathrm{Fe}, \mathrm{Mn})$. As a result, the benefit of solid solution strengthening of Mn could not be fully utilized. If intermetallic $\mathrm{Al}_{6}(\mathrm{Fe}, \mathrm{Mn})$ could be refined during solidification, its deteriorating effect could be inhibited, then a higher level of Mn could be accepted. Then, more Mn could be added to the alloy to improve its mechanical properties through solid solution strengthening. Finding a solution to refine the intermetallics during solidification was of great commercial interest for the production of the $\mathrm{Al}-\mathrm{Mg}$ based aluminum alloys.

Cooling rate could greatly influence the intermetallics formed during solidification in terms of size, amount, and morphology. Under near-rapid cooling, the intermetallics could be significantly refined or even inhibited [10]. The cooling rate used in the continuous strip casting (CC) process of aluminum alloy was about $10^{1}-10^{2}{ }^{\circ} \mathrm{C} \cdot \mathrm{s}^{-1}$, a near-rapid cooling. Intermetallic $\mathrm{Al}_{6}(\mathrm{Fe}, \mathrm{Mn})$ formed in this process could be significantly refined, and additional Mn could be added without the formation of coarse intermetallic $\mathrm{Al}_{6}(\mathrm{Fe}, \mathrm{Mn})$. Thus, a high-Mn-containing alloy with advanced mechanical properties could be developed and produced by using the CC process. The CC process has the advantage of high productivity and low production cost and has recently received wide attention from manufacturers and end users [11]. It was necessary and important to conduct research to study high-Mn-containing Al-Mg-Mn alloys solidified under near-rapid cooling.

Extensive research had been carried out on the Al-Mg-Mn alloys, and a large number of investigations focused on microstructures and properties [12-14], superplasticity [15-17], ultrafine grain [18-22], and adding element [23-26], etc. Al-Mg-Mn aluminum alloy sheet materials produced using the CC process have also been widely investigated [27-31]. However, little investigation has been made on the formation and control of the intermetallics in high-Mn-containing Al-Mg-Mn alloy solidified under near-rapid cooling.

This work investigated the intermetallics formed during solidification and the influence of $\mathrm{Mn}$, $\mathrm{Fe}$, and cooling rate on the formation of intermetallic $\mathrm{Al}_{6}(\mathrm{Fe}, \mathrm{Mn})$. Their effect on the microstructures and mechanical properties of $\mathrm{Al}-5 \mathrm{Mg}-\mathrm{Mn}$ alloys solidified under near-rapid cooling was reported elsewhere. The research simulated the CC process. The ultimate aim was to develop and produce a high-Mn-containing Al-Mg alloy with higher mechanical properties using the high productivity and low-cost CC process.

\section{Experimental Procedures}

A double-side water-cooled casting apparatus was designed to simulate the cooling of the CC process, as shown in Figure 1. The casting mold was $150 \mathrm{~mm} \times 150 \mathrm{~mm} \times 15 \mathrm{~mm}$ in size and was continuously cooled from two sides by injecting cold water. The cooling rate during casting was about $20^{\circ} \mathrm{C} \cdot \mathrm{s}^{-1}$, measured by recording the temperature evolution with time.

Two groups of Al-5Mg-Mn alloys were prepared. In each group, five alloys were designed with different Mn content, varying from $0.4 \mathrm{wt} \%$ to $2.0 \mathrm{wt} \%$. In the Group I alloys, the contents of iron and silicon were low $(<0.1 \mathrm{wt} \% \mathrm{Fe}$ and $<0.05 \mathrm{wt} \% \mathrm{Si})$. Higher contents of $\mathrm{Fe}$ and $\mathrm{Si}(0.5 \mathrm{wt} \% \mathrm{Fe}$ and $0.25 \mathrm{wt} \% \mathrm{Si}$ ) were used in the Group II alloys to study the combined effect of $\mathrm{Mn}, \mathrm{Fe}$, and $\mathrm{Si}$.

High grade commercial pure aluminum ingots with less than $0.10 \mathrm{wt} \%$ iron and less than $0.04 \mathrm{wt} \%$ silicon, magnesium ingots ( $99.9 \mathrm{wt} \%$ ), and Al-10Fe and Al-30Si master alloys were used to prepare the studied alloys. For each designed alloy, $2 \mathrm{~kg}$ of raw materials were melted in a graphite-clay crucible in an electric resistance furnace. After being degassed by injecting Ar into the pool and refined 
by adding Al-5Ti-B grain refiner, the molten aluminum, at around $725{ }^{\circ} \mathrm{C}$, was then poured into the apparatus shown in Figure 1. The chemical compositions of the cast slabs were determined by emission spectroscopy and listed in Table 1.

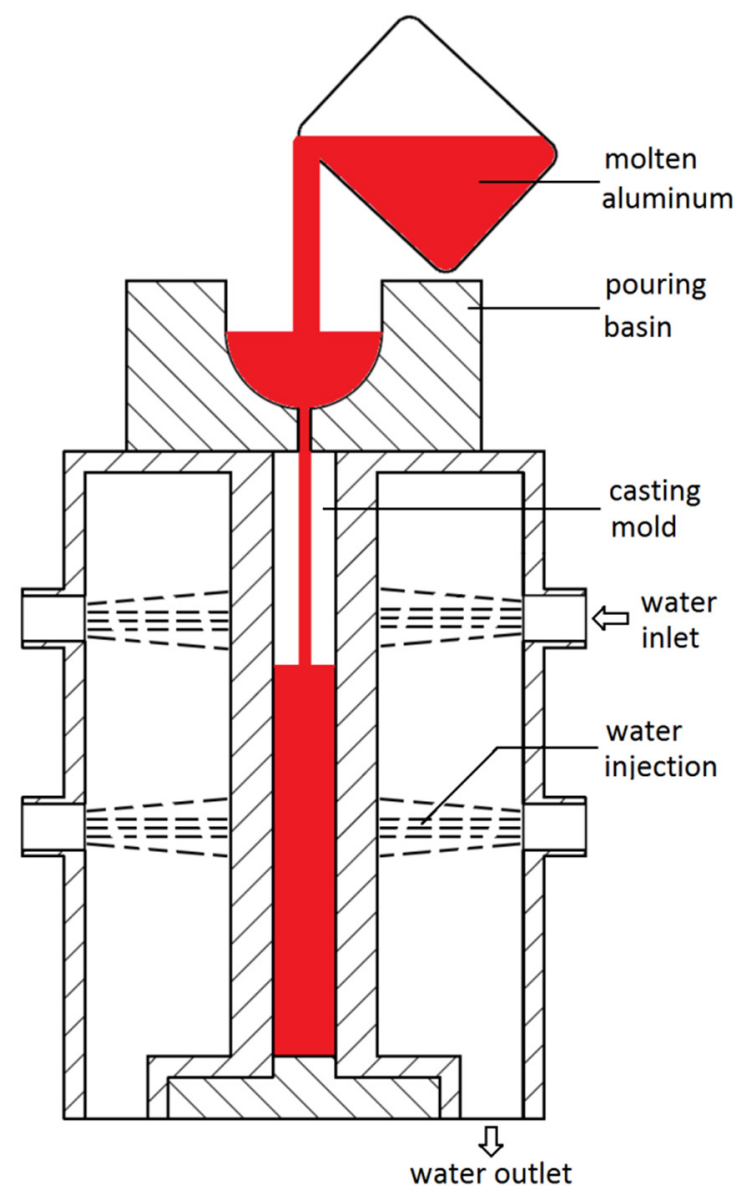

Figure 1. Schematic sketch of the double-side water cooling casting apparatus.

Table 1. Chemical composition of alloy samples, wt \%. Bal. means balance.

\begin{tabular}{|c|c|c|c|c|c|c|c|c|c|}
\hline \multirow{2}{*}{ Group } & \multirow{2}{*}{$\begin{array}{c}\text { Alloy } \\
\text { Sample }\end{array}$} & \multirow{2}{*}{$\begin{array}{c}\text { Nominal } \\
\text { Content of Mn }\end{array}$} & \multicolumn{7}{|c|}{ Measured Composition } \\
\hline & & & $\mathrm{Mg}$ & Mn & $\mathrm{Fe}$ & Si & $\mathrm{Cr}$ & Ti & Al \\
\hline \multirow{5}{*}{ I } & $\mathrm{I}-1$ & 0.4 & 4.75 & 0.39 & 0.085 & 0.034 & 0.006 & 0.018 & Bal. \\
\hline & $\mathrm{I}-2$ & 0.8 & 5.19 & 0.80 & 0.092 & 0.035 & 0.006 & 0.016 & Bal. \\
\hline & $\mathrm{I}-3$ & 1.2 & 5.08 & 1.29 & 0.085 & 0.033 & 0.006 & 0.016 & Bal. \\
\hline & $\mathrm{I}-4$ & 1.6 & 4.83 & 1.63 & 0.089 & 0.036 & 0.006 & 0.017 & Bal. \\
\hline & $\mathrm{I}-5$ & 2.0 & 5.13 & 2.10 & 0.098 & 0.034 & 0.006 & 0.017 & Bal. \\
\hline \multirow{5}{*}{ II } & II-1 & 0.4 & 4.81 & 0.39 & 0.455 & 0.233 & 0.006 & 0.017 & Bal. \\
\hline & II-2 & 0.8 & 4.87 & 0.73 & 0.485 & 0.241 & 0.006 & 0.023 & Bal. \\
\hline & II-3 & 1.2 & 4.82 & 1.23 & 0.473 & 0.219 & 0.006 & 0.018 & Bal. \\
\hline & II-4 & 1.6 & 5.12 & 1.51 & 0.502 & 0.238 & 0.006 & 0.022 & Bal. \\
\hline & II-5 & 2.0 & 4.83 & 2.00 & 0.556 & 0.230 & 0.006 & 0.024 & Bal. \\
\hline
\end{tabular}

In order to compare the as-cast microstructure of the alloys solidified under slow cooling, samples were cut from each cast slab and were re-melted and then solidified in alumina crucibles in an electric resistance furnace. The temperature evolutions with time were recorded. The average cooling rate before the start of solidification was approximately $0.065 \mathrm{~K} \mathrm{~s}^{-1}\left({ }^{\circ} \mathrm{C} \cdot \mathrm{s}^{-1}\right)$, which was calculated by using the formula $\mathrm{d} T / \mathrm{d} t$ and computed from the approximate straight line portion of the cooling curve. 
A series of interrupted water quenchings were conducted to reveal the solidification sequences of the alloy. During solidification, the temperature of the molten samples was monitored in-line by inserting the thermocouple into the molten samples. Once the predetermined temperature was reached, the solidification process was interrupted and the solidifying sample was quenched into cold water. The solidification process of the alloy could be revealed by differentiating between the solidified structure and the water-quenched structure of the samples. This method had been proven to work by the present author's previous work [32] and recently the work of Liu et al. [33].

An OLYMPUS GX71 optical microscope (OM) from Olympus Corporation (Shinjuku, Japan), a Zeiss scanning electron microscopy (SEM) with energy dispersive X-ray (EDX) analyzer from Zeiss Group (Oberkochen, Germany) and a X'pert Pro X-ray diffractometer (XRD) from PANalytical (Almelo, The Netherlands) were employed to analyze the intermetallics formed during solidification. The metallographic samples were prepared using standard metallographic procedures and electropolished at a voltage of $27 \mathrm{~V}$ DC for $15 \mathrm{~s}$ using $60 \mathrm{~mL} \mathrm{HClO}_{4}+140 \mathrm{~mL} \mathrm{H}_{2} \mathrm{O}+800 \mathrm{~mL} \mathrm{C}_{2} \mathrm{H}_{5} \mathrm{OH}$.

\section{Results}

\subsection{Intermetallics Formed under Near-Rapid Cooling}

The as-cast microstructures of the alloys cast under near-rapid cooling (approximately $20{ }^{\circ} \mathrm{C} \cdot \mathrm{s}^{-1}$ ) were identified by XRD analysis. They were affected by the contents of $\mathrm{Mn}, \mathrm{Fe}$, and Si. The XRD spectra of the Group I alloys were very simple. In the low-Mn alloys (Alloy I-1 and Alloy I-2), only $\alpha$-Al was detected, which was the matrix of the alloys. With the increase of Mn content in the alloys, the spectrum of intermetallic $\mathrm{Al}_{6}(\mathrm{Fe}, \mathrm{Mn})$ gradually became visible. It was relatively strong in Alloy $\mathrm{I}-5$. In the Group II alloys, the spectra of intermetallic $\mathrm{Al}_{6}(\mathrm{Fe}, \mathrm{Mn})$ was already quite strong in Alloy II- 1 with low Mn content and increased with increasing Mn content. Apart from $\mathrm{Al}_{6}(\mathrm{Fe}, \mathrm{Mn})$, intermetallic $\mathrm{Mg}_{2} \mathrm{Si}$ was also detected. XRD spectra showed the same mode in all the Group II alloys. Figure 2 shows the XRD spectra of two typical alloys. Two intermetallics $\mathrm{Al}_{6}(\mathrm{Fe}, \mathrm{Mn})$ and $\mathrm{Mg}_{2} \mathrm{Si}$ were read from the XRD analyses.

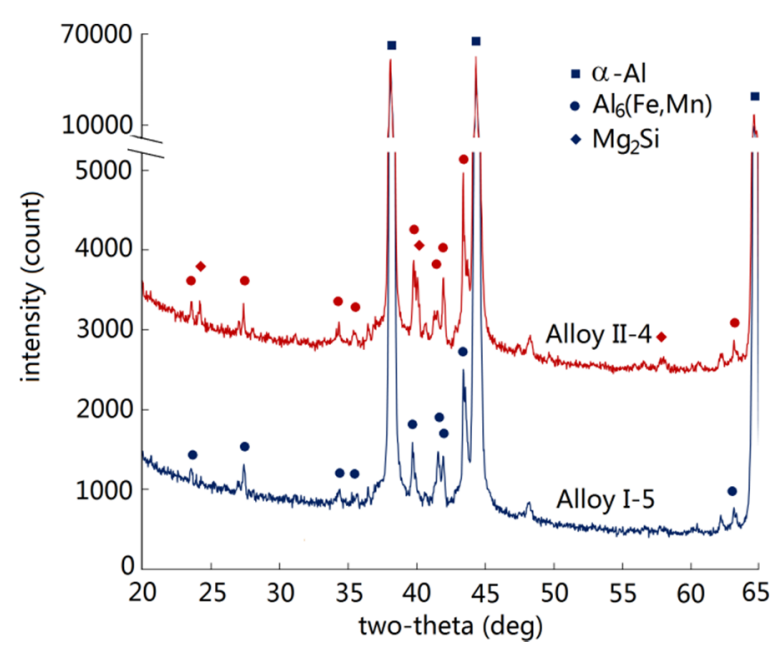

Figure 2. The XRD spectra of Alloy I-5 and Alloy II-4.

Figure 3 shows the as-cast microstructures of some typical Group I alloys solidified under near-rapid cooling. They consisted of $\alpha-\mathrm{Al}$ matrix and intermetallics. The intermetallic structures were quite simple: faceted, with a small blocky morphology. It was found by careful observation that they consisted of a major phase in light gray and a minor phase in dark gray. However, they were hard to distinguish in the metallographic photos. In Alloy I-1, the intermetallics were rare and small (Figure 3a). With the increase of Mn content in the alloys, the size and amount of the major intermetallic 
increased correspondingly. However, the increment was not remarkable. Even in Alloy I-4 with $1.6 \mathrm{wt} \% \mathrm{Mn}$, the intermetallic was not significantly increased (Figure 3b). Significant change of the major intermetallic occurred in Alloy I-5, with $2.0 \mathrm{wt} \%$ Mn (Figure 3c,d). In this sample, some extremely large platelet-like intermetallic was observed (Figure 3c). The intermetallic displayed a mixed structure of coarse platelet-like, small blocky, and Chinese script. The eutectic intermetallics were similar to the ones observed in Alloy I-4 (Figure 3d). In all the Group I alloys, the minor intermetallic was almost the same: very small in both size and amount.

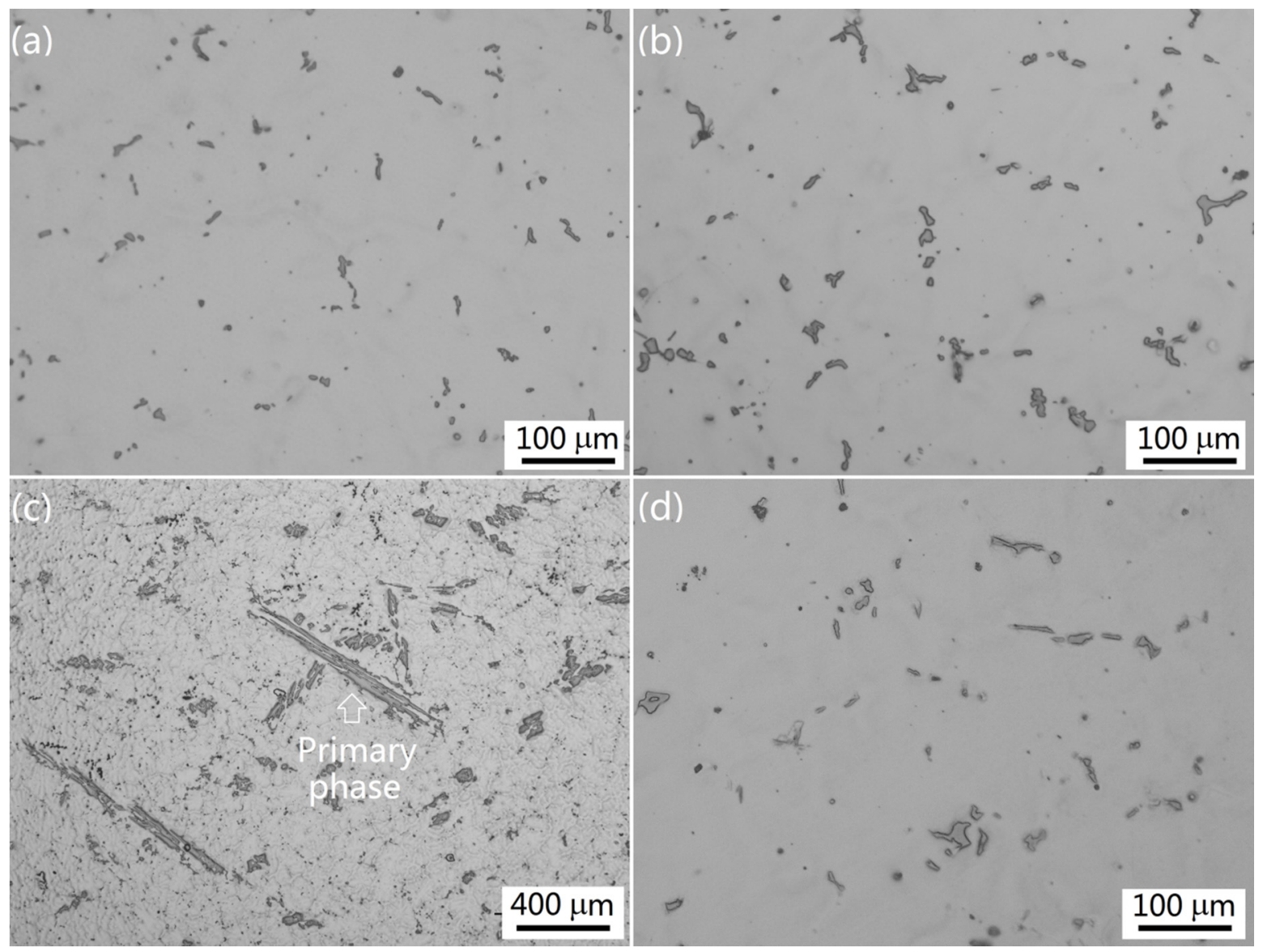

Figure 3. The as-cast microstructures of the Group I alloys solidified under near-rapid cooling: (a) Alloy I-1; (b) Alloy I-4; (c,d) Alloy I-5.

In the Group II alloys with high contents of Fe and Si, both the major intermetallic and the minor intermetallic significantly increased in terms of size and amount. They could be easily distinguished on the metallographic photos and were marked as A and B, respectively. Alloy II-1 displayed a large amount of the major intermetallic in Chinese script morphologies. The minor phase also showed Chinese script morphology, but was in a smaller amount than the major phase (Figure 4a). Compared to Alloy I-1, the as-cast microstructures significantly changed in Alloy II-1, as Fe and Si also participated in the formation of the intermetallics. As in the Group I alloys, increasing the Mn content in the Group II alloys also resulted in a corresponding increase in the size and amount of the major intermetallic. However, no change occurred to the minor phase in terms of size and amount. In Alloy II-3, some intermetallic became a flower-like structure. In addition, massive blocky or diamond shapes were also observed, as shown in Figure $4 \mathrm{~b}$. An extremely coarse platelet-like intermetallic appeared in Alloy II-4 which had a lower content of Mn than Alloy I-5. Most likely, in the alloys with a high Fe content, an extremely coarse platelet-like intermetallic formed at a relatively low content of Mn. In Alloy II-5 with $2.0 \mathrm{wt} \% \mathrm{Mn}$, the size and amount of the coarse platelet-like and diamond-like phases further 
increased. The morphology, distribution, size, and amount of the minor phase were almost the same in all of the Group II alloys.
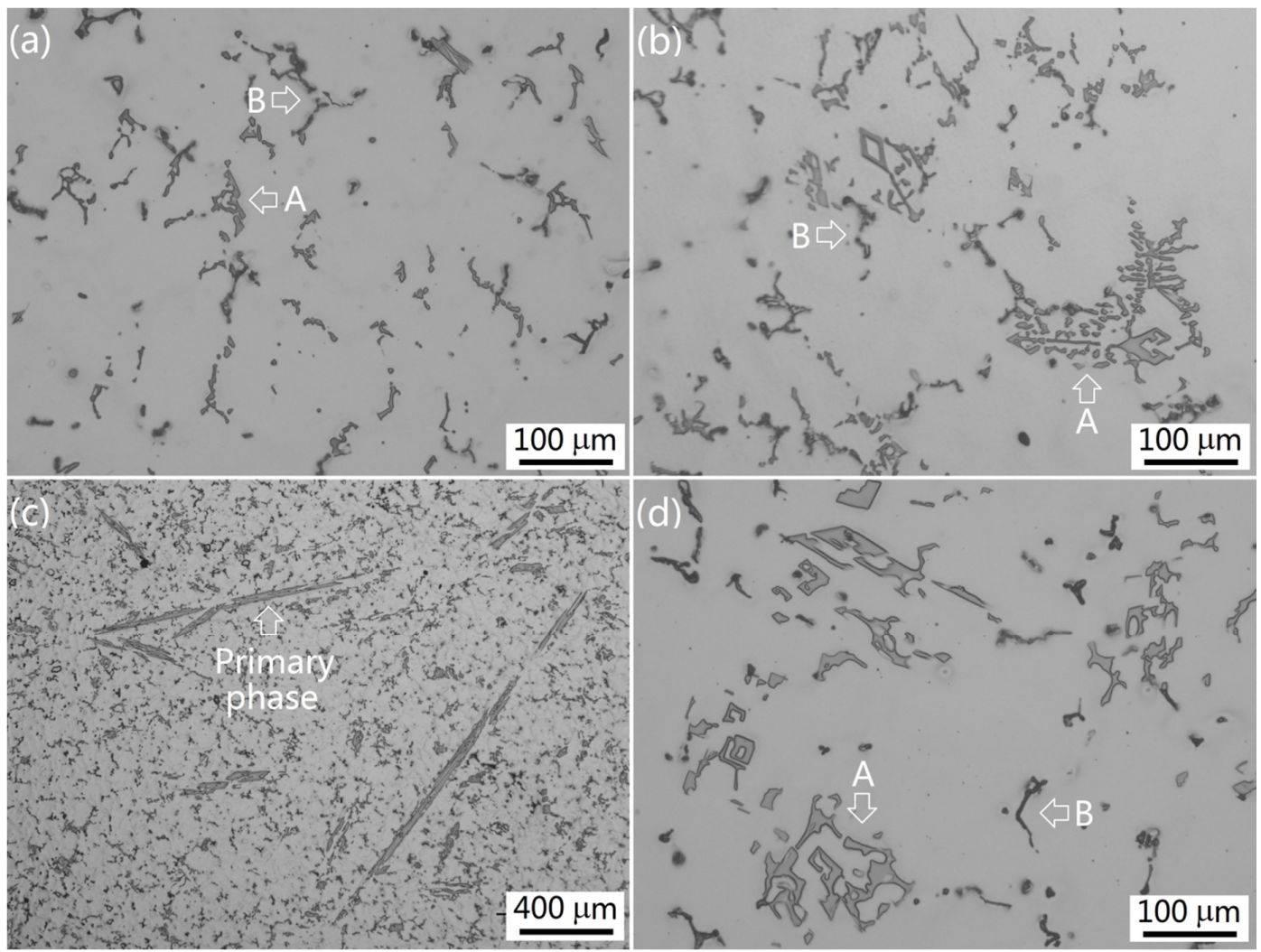

Figure 4. The as-cast microstructures of the Group II alloys solidified under near-rapid cooling (a) Alloy II-1; (b) Alloy II-3; (c,d) Alloy II-4.

The intermetallics were further studied by using SEM/EDX. Figure 5 shows the SEM backscattered electronic images of the typical morphologies of the major intermetallic and minor intermetallic at high magnification. Table 2 lists the results of the EDX analysis. It was found that, in both Group I and Group II alloys, the major intermetallic was Fe- and Mn-rich intermetallic; the minor intermetallic mainly contained $\mathrm{Mg}$ and $\mathrm{Si}$. The composition of the former was close to the formula $\mathrm{Al}_{6}(\mathrm{Fe}, \mathrm{Mn})$, but the composition of the latter did not meet the formula of any known phase. With the increase of Mn content, the composition formula of the major intermetallic was even closer to $\mathrm{Al}_{6}(\mathrm{Fe}, \mathrm{Mn})$; the concentration of $\mathrm{Fe}$ in the phases decreased slightly. The extremely coarse platelet-like intermetallic in Alloy I-5 had the same composition as the major intermetallic in the previous alloys. No remarkable change in composition was detected in the $\mathrm{Mg}$ - and Si-containing phase among the alloys.

Table 2. Composition of intermetallic $\mathrm{Al}_{6}(\mathrm{Fe}, \mathrm{Mn})$ measured by EDX (at \%).

\begin{tabular}{cccccc}
\hline \multirow{2}{*}{ Element } & \multicolumn{2}{c}{ Sample I-4 } & & \multicolumn{2}{c}{ Sample I-5 } \\
\cline { 2 - 3 } \cline { 5 - 6 } & $\begin{array}{c}\text { Composition } \\
\text { Range }\end{array}$ & $\begin{array}{c}\text { Composition } \\
\text { Average }\end{array}$ & & $\begin{array}{c}\text { Composition } \\
\text { Range }\end{array}$ & $\begin{array}{c}\text { Composition } \\
\text { Average }\end{array}$ \\
\hline $\mathrm{Al}$ & $76.32-85.19$ & 80.46 & & $83.41-86.00$ & 84.82 \\
$\mathrm{Mn}$ & $9.36-17.91$ & 14.96 & & $13.37-15.74$ & 14.38 \\
$\mathrm{Fe}$ & $1.88-3.35$ & 2.9 & & $0.63-0.91$ & 0.80 \\
$\mathrm{Mg}$ & $0-3.57$ & 1.71 & & 0 & 0 \\
\hline
\end{tabular}




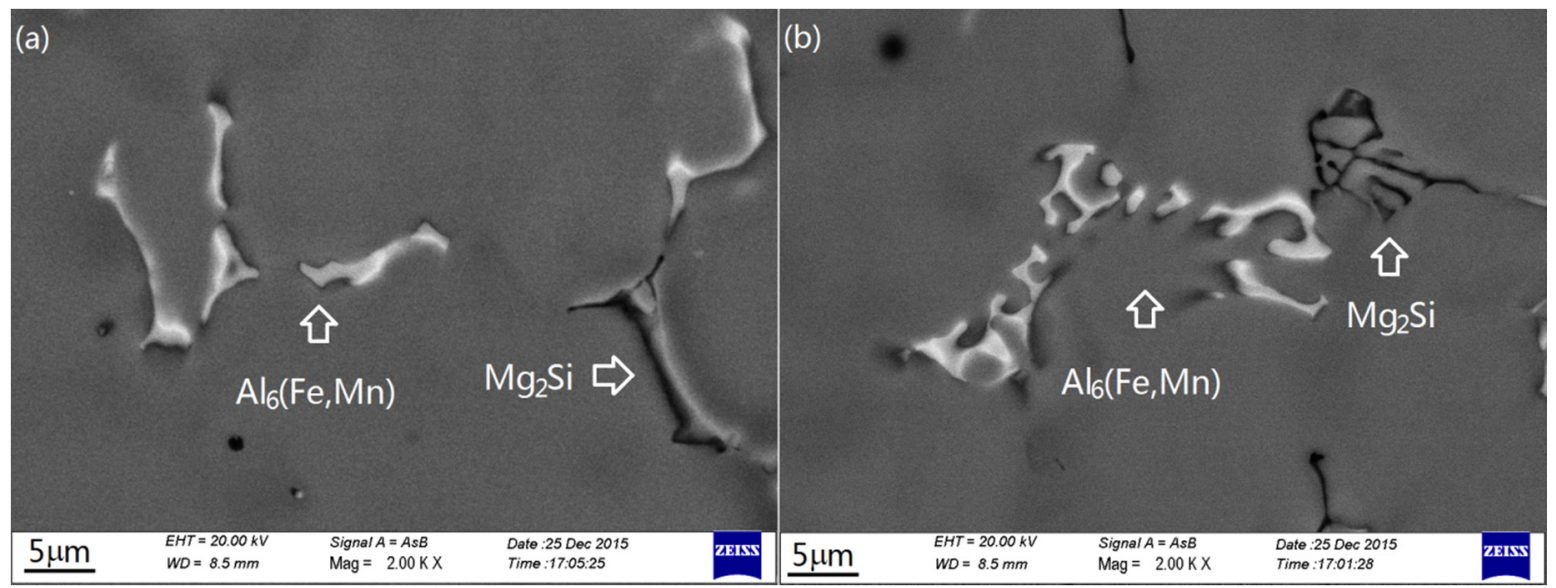

Figure 5. High magnification images of the intermetallics (a) Alloy I-4; (b) Alloy II-1.

The content of Fe had great influence on the major intermetallic. Although the composition of the major intermetallic in the Group II alloys were also close to the formula $\mathrm{Al}_{6}(\mathrm{Fe}, \mathrm{Mn})$, the concentration of Fe significantly increased and became the major element in the phase (Table 3). However, increasing $\mathrm{Si}$ in the Group II alloys did not change the composition of the Si- and Mg-containing phase. They still deviated from the stoichiometric ratio of $\mathrm{Mg}_{2} \mathrm{Si}$.

Table 3. Composition of intermetallic $\mathrm{Al}_{6}(\mathrm{Fe}, \mathrm{Mn})$ measured by EDX (at \%).

\begin{tabular}{cccccc}
\hline \multirow{2}{*}{ Element } & \multicolumn{2}{c}{ Alloy II-1 } & & \multicolumn{2}{c}{ Alloy II-4 } \\
\cline { 2 - 3 } \cline { 5 - 6 } & $\begin{array}{c}\text { Composition } \\
\text { Range }\end{array}$ & $\begin{array}{c}\text { Composition } \\
\text { Average }\end{array}$ & & $\begin{array}{c}\text { Composition } \\
\text { Range }\end{array}$ & $\begin{array}{c}\text { Composition } \\
\text { Average }\end{array}$ \\
\hline $\mathrm{Al}$ & $85.62-86.03$ & 85.83 & & $81.08-82.25$ & 81.83 \\
$\mathrm{Mn}$ & $2.17-2.34$ & 2.27 & & $12.08-13.53$ & 12.82 \\
$\mathrm{Fe}$ & $10.58-11.35$ & 10.95 & & $4.98-5.67$ & 5.35 \\
$\mathrm{Mg}$ & $0.74-1.09$ & 0.81 & & 0 & 0 \\
\hline
\end{tabular}

According to the analyses of XRD, SEM/EDX, and metallographic observation, it was certain that in all the alloys the major intermetallic was the $\mathrm{Al}_{6}(\mathrm{Fe}, \mathrm{Mn})$ phase. The extremely coarse platelet-like intermetallic in Alloys I-5, II-4 and II-5 was also $\mathrm{Al}_{6}(\mathrm{Fe}, \mathrm{Mn})$. Most likely, they precipitated as the primary phase during solidification. Although the EDX-measured composition of the minor intermetallic did not meet the stoichiometric formula of $\mathrm{Mg}_{2} \mathrm{Si}$, considering the fact that the $\mathrm{Mg}_{2} \mathrm{Si}$ spectrum was detected by XRD, most likely, this minor intermetallic was the $\mathrm{Mg}_{2} \mathrm{Si}$ phase. The aluminum detected in the phase was from the matrix.

Figure 6 shows the deep-etched images of the Alloy II-5 intermetallics. After deep-etching with $\mathrm{NaOH}$ water solution for $1 \mathrm{~min}$, some square-pillar like structure appeared. It could be seen that the platelet-like and square shapes observed under OM (Figure 4c) were the longitudinal and transversal cross sections of the square pillar, respectively. The complicated structure with a coral-like morphology should correspond to the Chinese script-like $\mathrm{Al}_{6}(\mathrm{Fe}, \mathrm{Mn})$. The $\mathrm{Mg}_{2} \mathrm{Si}$ phase was relatively simple with a small blocky structure (Figure 6c). In addition, it was worth noting that some microcracks appeared on the square pillar and coral-like $\mathrm{Al}_{6}(\mathrm{Fe}, \mathrm{Mn})$, especially present in the square pillar. 

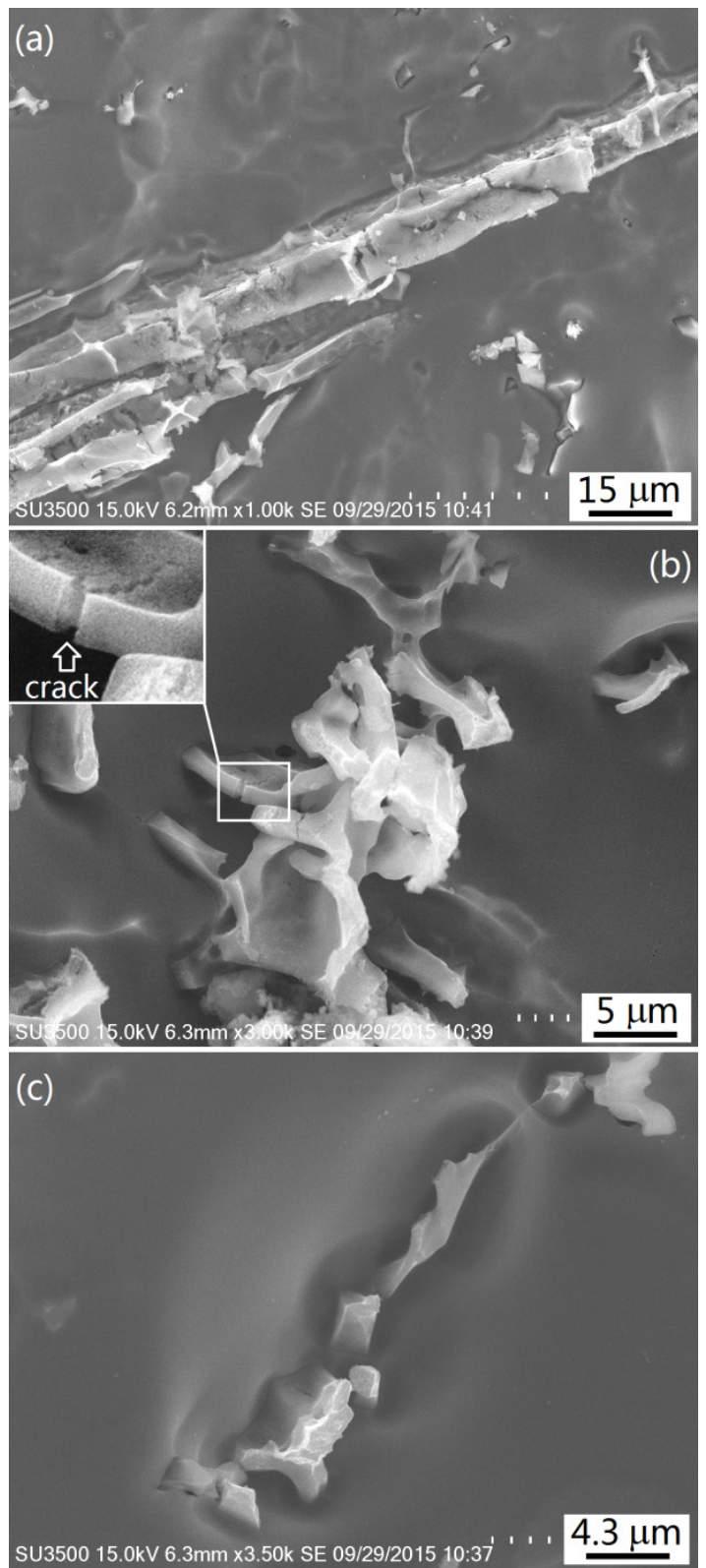

Figure 6. The deep etched images of the intermetallics: (a) Primary $\mathrm{Al}_{6}(\mathrm{Fe}, \mathrm{Mn})$; (b) eutectic $\mathrm{Al}_{6}(\mathrm{Fe}, \mathrm{Mn})$; (c) $\mathrm{Mg}_{2} \mathrm{Si}$.

\subsection{Intermetallics Formed under Slow Cooling}

In order to compare the microstructure of the near-rapid cooled alloys with the direct-chill (DC) casting process cooled alloys, the alloys were remelted and solidified at a cooling rate of approximately $0.065^{\circ} \mathrm{C} \cdot \mathrm{s}^{-1}$, which simulated the solidification of DC cast ingot. It was found that the as-cast microstructures of the alloys were essentially the same as described above. They still consisted of $\alpha$ - $\mathrm{Al}$ matrix and intermetallics $\mathrm{Al}_{6}(\mathrm{Fe}, \mathrm{Mn})$ and $\mathrm{Mg}_{2} \mathrm{Si}$. However, their size, amount, morphologies, and distribution were completely different, especially in the high-Mn alloys. In the Group I alloys, intermetallic $\mathrm{Al}_{6}(\mathrm{Fe}, \mathrm{Mn})$ of Alloy I- 1 was very small in both size and amount and appeared to be quite faceted with a blocky morphology. With the increase of Mn content in the alloy, intermetallic $\mathrm{Al}_{6}(\mathrm{Fe}, \mathrm{Mn})$ gradually increased in size and amount. In Alloy I-3 with $1.2 \mathrm{wt} \% \mathrm{Mn}$, intermetallic $\mathrm{Al}_{6}(\mathrm{Fe}, \mathrm{Mn})$ branched. Increasing the Mn content to $1.6 \mathrm{wt} \%$ (Alloy I-4), the morphologies of $\mathrm{Al}_{6}(\mathrm{Fe}, \mathrm{Mn})$ became complicated with flower-like or Chinese script shapes (Figure 7a). In Alloy I-5 with $2.0 \mathrm{wt} \%$ 
$\mathrm{Mn}$, the $\mathrm{Al}_{6}(\mathrm{Mn}, \mathrm{Fe})$ phase increased significantly in both amount and size. A large amount of massive platelet-like $\mathrm{Al}_{6}\left(\mathrm{Fe}, \mathrm{Mn}\right.$ ) was observed (Figure $7 \mathrm{~b}$ ). Intermetallic $\mathrm{Mg}_{2} \mathrm{Si}$ showed irregular morphologies and were very small in both size and amount in all the Group I alloys.

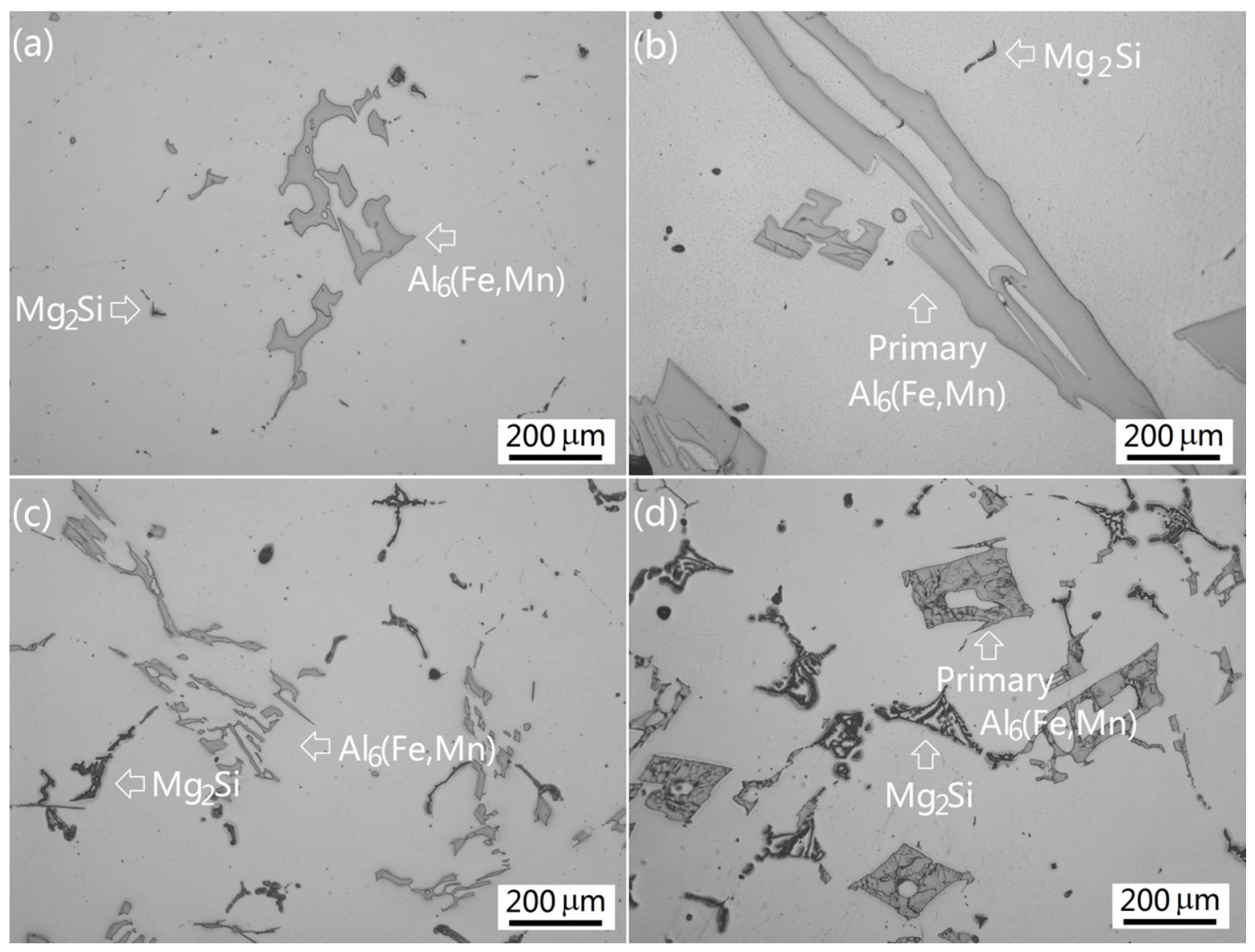

Figure 7. The as-cast microstructures of the alloys solidified under slow cooling (a) Alloy I-4; (b) Alloy I-5; (c) Alloy II-1; (d) Alloy II-4.

The solidification structures of the Group II alloys still consisted of $\alpha$-Al matrix and intermetallics $\mathrm{Al}_{6}(\mathrm{Fe}, \mathrm{Mn})$ and $\mathrm{Mg}_{2} \mathrm{Si}$. In Alloy II-1, $\mathrm{Al}_{6}(\mathrm{Fe}, \mathrm{Mn})$ turned into complicated flower-like structures in large sizes; $\mathrm{Mg}_{2} \mathrm{Si}$ turned into network and Chinese script structures (Figure 7c). With the increase of Mn content, the amount and size of $\mathrm{Al}_{6}(\mathrm{Fe}, \mathrm{Mn})$ increased accordingly. Figure $7 \mathrm{~d}$ shows the extremely large square-shaped primary $\mathrm{Al}_{6}(\mathrm{Fe}, \mathrm{Mn})$ in Alloy II-4. The as-cast microstructure was extremely coarse. In Alloy II-5, intermetallic $\mathrm{Al}_{6}(\mathrm{Fe}, \mathrm{Mn})$ further increased in both size and amount.

\subsection{The Solidification Process}

Figure 8 shows the cooling curves of the four typical alloys during solidification at a cooling rate of approximately $0.065^{\circ} \mathrm{C} \cdot \mathrm{s}^{-1}$. It can be seen that all the alloys had an inflexion at around $634^{\circ} \mathrm{C}$. These inflexion points correspond to the start of solidification of the $\alpha$-Al matrix. In addition, on the curves of Alloy I-5 and Alloy II-4, an inflexion was detected at $657^{\circ} \mathrm{C}$ and $653{ }^{\circ} \mathrm{C}$, respectively. On the curves of Alloy II-1 and Alloy II-4, an inflexion was detected at $582{ }^{\circ} \mathrm{C}$. It was assumed that the inflexions at $657^{\circ} \mathrm{C}$ and $653^{\circ} \mathrm{C}$ corresponded to the precipitation of the primary intermetallic $\mathrm{Al}_{6}(\mathrm{Fe}, \mathrm{Mn})$; the inflexion at $582{ }^{\circ} \mathrm{C}$ corresponded to the precipitation of the intermetallic $\mathrm{Mg}_{2} \mathrm{Si}$. 


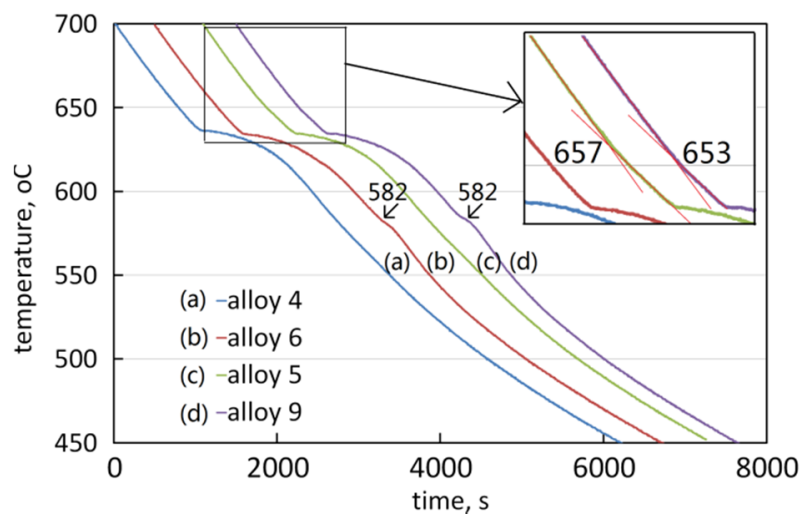

Figure 8. The cooling curves of the alloys.

In order to confirm the precipitation of the primary phase, a series of interrupted water quenchings was performed during the cooling of Alloy I-4 and Alloy I-5. When Alloy I-4 cooled to $630^{\circ} \mathrm{C}$, which was lower than the assumed precipitation temperature of $\alpha-\mathrm{Al}$, the cooling sample was quenched into cold water. In the quenched sample, no intermetallic $\mathrm{Al}_{6}(\mathrm{Fe}, \mathrm{Mn})$ was discovered. This confirmed that the primary phase was $\alpha$-Al. Alloy I- 5 was quenched into cold water when it cooled to $650{ }^{\circ} \mathrm{C}$, which was much higher than the assumed precipitation temperature of $\alpha$-Al. Intermetallic $\mathrm{Al}_{6}(\mathrm{Fe}, \mathrm{Mn})$ had already precipitated in the quenched sample, see Figure 9. These experiments confirmed that Alloy I-4 was still hypoeutectic, $\alpha$-Al was the primary phase. However, Alloy I- 5 was hypereutectic, intermetallic $\mathrm{Al}_{6}(\mathrm{Fe}, \mathrm{Mn})$ became the primary phase. These results agreed with the deduction mentioned above.

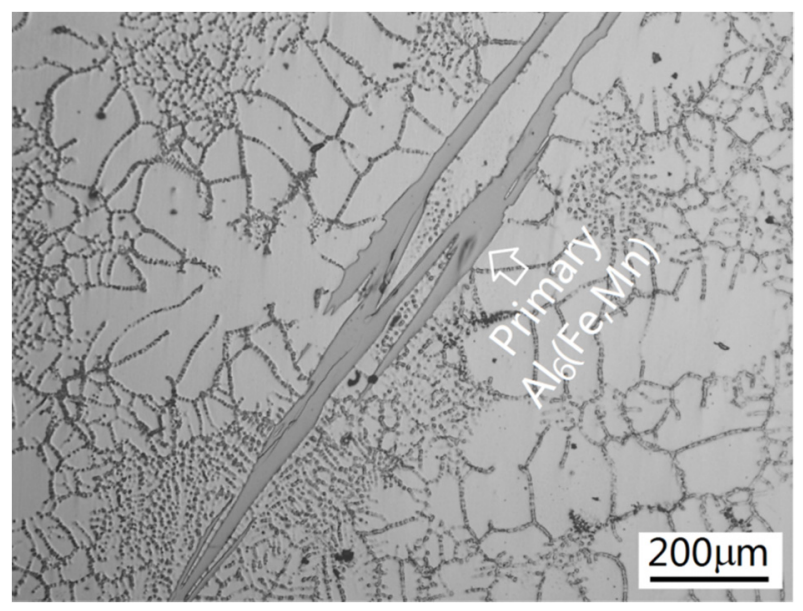

Figure 9. The microstructures of Alloy I-5 after interrupted quenching at $650^{\circ} \mathrm{C}$.

\section{Discussion}

The as-cast intermetallic structures were significantly affected by the contents of Mn and Fe and cooling rate in terms of size, amount, morphology, and distribution.

\subsection{The Influence of $\mathrm{Mn}$ and Fe}

According to the Al-Mn binary diagram [34], the redistribution coefficient of $\mathrm{Mn}$ in $\mathrm{Al}$ was about 0.95. Therefore, the segregation tendency of Mn was quite small. According to the Scheil equation:

$$
C_{L}=C_{0} \cdot f_{L}^{(k-1)}
$$


where $k$ is the redistribution coefficient of $\mathrm{Mn}, C_{0}$ is the initial concentration of $\mathrm{Mn}$ in the alloy, $C_{L}$ is the concentration of $\mathrm{Mn}$ in the liquid in interface front, and $f_{L}$ is the fractional volume of remaining liquid.

During solidification, the buildup of Mn concentration in the interface front was very limited. Most of the Mn atoms were in solid solution in the matrix. In the alloy with low Mn content, the final solidification zones that reached the eutectic composition were limited in both size and number. Therefore, the intermetallics formed during solidification were small in both size and amount. With the increase of Mn content in the alloys, the concentration of Mn at the interface front increased, which resulted in the increase in the number of final solidification zones that reached eutectic composition. However, according to Equation (1), the increment was limited. Therefore, increasing the Mn content in the alloys increased the amount of Mn atoms in solid solution in the matrix, but did not significantly increase the fraction of eutectic intermetallics. If the eutectic intermetallics could be refined to avoid the deteriorating effect of the coarse intermetallic, increasing Mn content in the alloys could result in the increase of strength by solution strengthening. This favors improving the mechanical properties of the alloy by increasing the Mn content.

On the other hand, once the Mn content passed beyond the eutectic point, intermetallic $\mathrm{Al}_{6}(\mathrm{Fe}, \mathrm{Mn})$ became the primary phase, then the eutectic reaction $\mathrm{L} \rightarrow \alpha-\mathrm{Al}+\mathrm{Al}_{6}(\mathrm{Fe}, \mathrm{Mn})$ followed. Therefore, almost all of the $\mathrm{Mn}$ atoms would form intermetallic $\mathrm{Al}_{6}(\mathrm{Fe}, \mathrm{Mn})$, which was large in both size and amount. The amount of Mn atoms in solid solution was limited. In this case, increasing Mn content in the alloys would result in the deterioration of the mechanical properties.

From the Al-Fe phase diagram [35], the redistribution coefficient of Fe in Al was about 0.022. Therefore, the segregation tendency of Fe was very high. Almost all the Fe segregated into the interface front and formed Fe-rich intermetallic during solidification. Increasing the content of Fe in the alloy would significantly increase the volume fraction of the Fe-rich intermetallic. In Al-Mg alloys, for example the AA5005 alloy, Fe combined with $\mathrm{Al}$ to form $\mathrm{Al}_{3} \mathrm{Fe}$ [1]. Adding $\mathrm{Mn}$ gave rise to the formation of Fe- and Mn-rich intermetallic. Early work [36] showed that the three phases $\mathrm{Al}_{6} \mathrm{Mn}$, $\mathrm{Al}_{6}(\mathrm{Mn}, \mathrm{Fe})$, and $\mathrm{Al}_{6} \mathrm{Fe}$ were isomorphous. In the alloy system that contained both $\mathrm{Mn}$ and $\mathrm{Fe}, \mathrm{Fe}$ combined with $\mathrm{Mn}$ to form Fe- and Mn-rich intermetallic $\mathrm{Al}_{6}(\mathrm{Fe}, \mathrm{Mn})$. The amount of $\mathrm{Al}_{6}(\mathrm{Fe}, \mathrm{Mn})$ formed during solidification depended on the contents of both $\mathrm{Mn}$ and Fe. In the alloys with low Fe content, increasing the content of $\mathrm{Mn}$ to $1.6 \mathrm{wt} \%$ did not cause the formation of primary $\mathrm{Al}_{6}(\mathrm{Fe}, \mathrm{Mn})$. The amount of intermetallic $\mathrm{Al}_{6}(\mathrm{Fe}, \mathrm{Mn})$ formed was quite small. However, in the high $\mathrm{Fe}$ alloy, $\mathrm{Fe}$ caused the formation of a large amount of intermetallic $\mathrm{Al}_{6}(\mathrm{Fe}, \mathrm{Mn})$. Increasing $\mathrm{Mn}$ would give rise to the further increase of the intermetallic. Therefore, there existed a large amount of intermetallic $\mathrm{Al}_{6}(\mathrm{Fe}, \mathrm{Mn})$ in all the Group II alloys. Since both $\mathrm{Mn}$ and Fe contributed to the formation of intermetallic $\mathrm{Al}_{6}(\mathrm{Fe}, \mathrm{Mn})$, the eutectic composition of $\mathrm{Mn}$ for the reaction of $\mathrm{L} \rightarrow \alpha-\mathrm{Al}+\mathrm{Al}_{6}(\mathrm{Fe}, \mathrm{Mn})$ would be lower than for the reaction of $\mathrm{L} \rightarrow \alpha-\mathrm{Al}+\mathrm{Al}_{6} \mathrm{Mn}$. Therefore, primary intermetallic $\mathrm{Al}_{6}(\mathrm{Fe}, \mathrm{Mn})$ was observed in Alloy II-4. As a result, the limit of Mn in the alloy composition specification had to be reduced in order to avoid the formation of coarse primary intermetallic $\mathrm{Al}_{6}(\mathrm{Fe}, \mathrm{Mn})$.

In this study, Si combined with $\mathrm{Mg}$ to form the $\mathrm{Mg}_{2} \mathrm{Si}$ phase. No AlFeSi or AlFeMnSi phase was observed. On the other hand, Si also had a great influence on the Fe- and Mn-rich intermetallics. A research on $\mathrm{Al}-5 \mathrm{Mg}-0.8 \mathrm{Mn}$ alloy with $0.5 \mathrm{wt} \% \mathrm{Fe}$ and $0.5 \mathrm{wt} \% \mathrm{Si}$ indicated that the Si-containing intermetallic would change to the quaternary phase $\mathrm{Al}_{15}(\mathrm{Fe}, \mathrm{Mn})_{3} \mathrm{Si}$ with fine fish bone or Chinese script structure when the alloy was solidified under near-rapid cooling [37].

\subsection{The Influence of Cooling Rate}

Comparing the intermetallic structures of the alloys formed under near-rapid cooling and slow cooling, it could be found that cooling rate played a key role in the control of the intermetallic structures. Increasing the cooling rate to $20^{\circ} \mathrm{C} \cdot \mathrm{s}^{-1}$, the intermetallics were extremely refined. Even in the alloy with high content of $\mathrm{Fe}$ and $\mathrm{Mn}$, the intermetallics were still small in size.

During solidification, with the growth of primary $\alpha-\mathrm{Al}$, the solutes $\mathrm{Mn}$ and Fe segregated into and enriched at the interface front. Once the composition of the remaining liquid in the final 
solidification zones reached the eutectic composition, the eutectic reaction $\mathrm{L} \rightarrow \alpha-\mathrm{Al}+\mathrm{Al}_{6}(\mathrm{Fe}, \mathrm{Mn})$ occurred. Increasing cooling rate during solidification would result in the decrease of the segregation tendency of the solute atoms and grains. Therefore, the higher the cooling rate, the less the solute atoms segregated into interface front. On the other hand, the decrease of the grain sizes affected the refinement of the intermetallics from two aspects. In general, the final solidification zones were the regions with triangle grain boundaries and inter-dendrites. The refinement of the grains resulted in the increase of regions with triangle grain boundaries and inter-dendrites (final solidification zones) and the decrease of the concentration of solute atoms at the interface front. As a result, the regions in which the concentration of solutes reached the eutectic point increased in amount and decreased in size. The intermetallics formed in the final solidification zones were extremely refined.

Mn had been added to Al-Mg-based alloys to compensate for the negative effect of Fe on the mechanical properties and achieve solid solution strengthening. Increasing the content of Mn would increase the mechanical properties of the Al-Mg-based alloy by increasing solid solution strengthening. For example, tensile strength of the Al-5Mg-Mn alloy at $\mathrm{O}$ temper increased $15 \mathrm{MPa}$ when increasing the Mn content from $0.35 \mathrm{wt} \%$ (AA5082 alloy) to $0.7 \mathrm{wt} \%$ (AA5083 alloy). However, further increase of $\mathrm{Mn}$ would cause the formation of coarse intermetallic $\mathrm{Al}_{6}(\mathrm{Fe}, \mathrm{Mn})$ during solidification, as observed in Alloy II-3, and would lead to significant degradation of the alloy's mechanical properties [2,3]. The deteriorating effect of the intermetallics on the mechanical properties of the alloys was related to the size, amount and morphology of the intermetallics. The coarse intermetallics would break into coarse particles with sharp edges and corners during hot and cold rolling and leave cavities among the fragments. These coarse particles and cavities were very harmful to the mechanical properties. The higher the content of $\mathrm{Mn}$ in the alloy, the coarser the intermetallics formed during solidification, and the coarser the particles remained in the hot band and cold rolled sheet. The solidification process under slow cooling in this study was similar to the situation of traditional direct chill casting. Therefore, in the traditional production practice, the concentration of Mn must be limited to a low level in order to avoid the formation of coarse manganese-rich constituents. The solid solution strengthening effect of Mn could not be fully used.

On the other hand, the intermetallics could be significantly refined by increasing cooling rate during solidification. As mentioned above, intermetallic $\mathrm{Al}_{6}(\mathrm{Fe}, \mathrm{Mn})$ was extremely refined by the near-rapid cooling during solidification (Figures 3 and 4). It was assumed that the particles created from those intermetallics during hot rolling and/or cold rolling would be fine and possess less deteriorating effect on the mechanical properties. As a result, under the condition of near-rapid cooling, the content of $\mathrm{Mn}$ in the alloys could be increased to a higher level and fully utilize the advantage of solid solute strengthening of Mn.

The near-rapid cooling used in this study was comparable to the cooling in the continuous strip casting process. For the production of Al-Mg-based alloy sheets via the CC process, most likely, the limits of Mn could be increased to a higher level to achieve improved mechanical properties.

\section{Conclusions}

1) In $\mathrm{Al}-5 \mathrm{Mg}-\mathrm{Mn}$ alloy with low Fe content, intermetallic $\mathrm{Al}_{6}(\mathrm{Fe}, \mathrm{Mn})$ was small in size and amount. With the increase of $\mathrm{Mn}$, intermetallic $\mathrm{Al}_{6}(\mathrm{Fe}, \mathrm{Mn})$ increased, but the increment was limited. Once the content of $\mathrm{Mn}$ passed beyond eutectic, intermetallic $\mathrm{Al}_{6}(\mathrm{Fe}, \mathrm{Mn})$ became the primary phase with extremely coarse platelet-like morphology and increased significantly in amount;

2) In high-Fe-containing $\mathrm{Al}-5 \mathrm{Mg}-\mathrm{Mn}$ alloys, Fe promoted the formation of intermetallic $\mathrm{Al}_{6}(\mathrm{Fe}, \mathrm{Mn})$. Even in the alloy with low Mn content, it was in a large amount. With the increase of Mn content, intermetallic $\mathrm{Al}_{6}(\mathrm{Fe}, \mathrm{Mn})$ increased in both size and amount. Increasing the content of Fe caused intermetallic Al6(Fe,Mn) to become the primary phase at a lower Mn content; 
3) Cooling rate played a critical role in the refinement of intermetallics. $\mathrm{The}^{\mathrm{Al}} \mathrm{Al}_{6}(\mathrm{Fe}, \mathrm{Mn})$ phase could be refined to a significant extent by casting under near-rapid cooling (around $20^{\circ} \mathrm{C} \cdot \mathrm{s}^{-1}$ ). In the alloys with high $\mathrm{Mn}$ and/or high Fe contents solidified under near-rapid cooling, intermetallic $\mathrm{Al}_{6}(\mathrm{Fe}, \mathrm{Mn})$ demonstrated fine Chinese script structures, which could be achieved using the continuous strip casting process.

Acknowledgments: The authors are grateful to the Research Foundation of Shenyang Aerospace University for its financial support.

Author Contributions: All the co-authors of the paper have contributed to the research. Gaoren Huang and Yimeng Sun performed the experiments; Li Zhang operated SEM; Zhenwei Huang analyzed the XRD data; Jijie Wang and Chunzhong Liu contributed the discussion of the experiments; Yulin Liu designed the experiments and wrote the paper.

Conflicts of Interest: The authors declare no conflict of interest.

\section{References}

1. Backerud, L.; Krol, E.; Tamminen, J. Solidification Characteristics of Aluminum Alloys; Universitetsforlaget AS: Osle, Norway, 1986; p. 113.

2. Seifeddine, S.; Johansson, S.; Svensson, I.L. The influence of cooling rate and manganese content on the $\beta-\mathrm{Al}_{5} \mathrm{FeSi}$ phase formation and mechanical properties of Al-Si-based alloys. Mater. Sci. Eng. A 2008, 490, 385-390. [CrossRef]

3. Sreeja Kumari, S.S.; Pillai, R.M.; Rajan, T.P.D.; Pai, B.C. Effects of individual and combined additions of Be, $\mathrm{Mn}, \mathrm{Ca}$ and $\mathrm{Sr}$ on the solidification behaviour, structure and mechanical properties of $\mathrm{Al}-7 \mathrm{Si}-0.3 \mathrm{Mg}-0.8 \mathrm{Fe}$ alloy. Mater. Sci. Eng. A 2007, 460, 561-573. [CrossRef]

4. Liu, K.; Cao, X.; Chen, X.G. Tensile Properties of Al-Cu 206 Cast Alloys with Various Iron Contents. Metall. Mater. Trans. A 2014, 45, 2498-2507. [CrossRef]

5. Li, J.; Birbilis, N.; Buchheit, R.G. Electrochemical Assessment of Interfacial Characteristics of Intermetallic Phases Present in Aluminium Alloy 2024-T3. Corros. Sci. 2015, 101, 155-164. [CrossRef]

6. Cavanaugh, M.K.; Li, J.-C.; Buchheit, R.G. Electrochemical characterization of intermetallic phases common to aluminum alloys as a function of solution temperature. J. Electrochem. Soc. 2014, 161, C535-C543. [CrossRef]

7. Davis, J.R. Alloying: Understanding the Basics; ASM International: Novelty, OH, USA, 2001; p. 382.

8. Backerud, L.; Krol, E.; Tamminen, J. Solidification Characteristics of Aluminum Alloys; Universitetsforlaget AS: Osle, Norway, 1986; p. 119.

9. Bauccio, M.L. ASM Metals Reference Book, 3rd ed.; ASM International: Novelty, OH, USA, 1993; pp. $405-415$.

10. Liu, Y.L.; Liu, M.; Luo, L.; Wang, J.Z.; Liu, C.Z. The Solidification Behavior of AA2618 Aluminum Alloy and the Influence of Cooling Rate. Materials 2014, 7, 7875-7890. [CrossRef]

11. Sanders, R.E., Jr. Continuous Casting for Aluminum Sheet: A Product Perspective. JOM 2012, 64, $291-301$. [CrossRef]

12. Goswami, R.; Spanos, G.; Pao, P.S.; Holtz, R.L. Microstructural evolution and stress corrosion cracking behavior of Al-5083. Metall. Mater. Trans. A 2011, 42, 348-355. [CrossRef]

13. Goswami, R.; Holtz, R.L. Transmission electron microscopic investigations of grain boundary beta phase precipitation in $\mathrm{Al} 5083$ aged at $373 \mathrm{~K}\left(100^{\circ} \mathrm{C}\right)$. Metall. Mater. Trans. A 2013, 44, 1279-1289. [CrossRef]

14. Harrell, T.J.; Topping, T.D.; Wang, H.M.; Hu, T.; Schoenung, J.M.; Lavernia, E.J. Microstructure and strengthening mechanisms in an ultrafine grained Al-Mg-Sc alloy produced by powder metallurgy. Metall. Mater. Trans. A 2014, 45, 6329-6343. [CrossRef]

15. Verma, R.; Kim, S. Superplastic behavior of copper-modified 5083 aluminum alloy. J. Mater. Eng. Perform. 2007, 16, 185-191. [CrossRef]

16. Smolej, A.; Skaza, B.; Dragojević, V. Superplastic behavior of Al-4.5Mg-0.46Mn-0.44Sc alloy sheet produced by a conventional rolling process. J. Mater. Eng. Perform. 2010, 19, 221-230. [CrossRef]

17. Shin, D.H.; Hwang, D.-Y.; Oh, Y.-J.; Park, K.-T. High-strain-rate superplastic behavior of equal-channel angular-pressed 5083 Al-0.2 wt pct Sc. Metall. Mater. Trans. A 2004, 35, 825-837. [CrossRef] 
18. Singh, D.; Rao, P.N.; Jayaganthan, R. Effect of deformation temperature on mechanical properties of ultrafine grained Al-Mg alloys processed by rolling. Mater. Des. 2013, 50, 646-655. [CrossRef]

19. Abdu, M.T.; Dheda, S.S.; Lavernia, E.J.; Topping, T.D.; Mohamed, F.A. Creep and microstructure in ultrafine-grained 5083 Al. J. Mater. Sci. 2013, 48, 3294-3303. [CrossRef]

20. Topping, T.D.; Ahn, B.; Li, Y.; Nutt, S.R.; Lavernia, E.J. Influence of process parameters on the mechanical behavior of an ultrafine-grained Al alloy. Metall. Mater. Trans. A 2012, 43, 505-519. [CrossRef]

21. Roy, I.; Chauhan, M.; Mohamed, F.A.; Lavernia, E.J. Thermal stability in bulk cryomilled ultrafine-grained $5083 \mathrm{Al}$ alloy. Metall. Mater. Trans. A 2006, 37, 721-730. [CrossRef]

22. Witkin, D.; Han, B.Q.; Lavernia, E.J. Mechanical behavior of ultrafine-grained cryomilled Al 5083 at elevated temperature. J. Mater. Eng. Perform. 2005, 14, 519-527. [CrossRef]

23. Lin, S.; Nie, Z.; Huang, H.; Li, B. Annealing behavior of a modified 5083 aluminum alloy. Mater. Des. 2010, 31, 1607-1612. [CrossRef]

24. Yang, D.; Li, X.; He, D.; Huang, H. Effect of minor Er and Zr on microstructure and mechanical properties of Al-Mg-Mn alloy (5083) welded joints. Mater. Sci. Eng. A 2013, 561, 226-231.

25. Malopheyev, S.; Kaibyshev, R. Strengthening mechanisms in a Zr-modified 5083 alloy deformed to high strains. Mater. Sci. Eng. A 2015, 620, 246-252. [CrossRef]

26. Meng, C.; Zhang, D.; Cui, H.; Zhuang, L.; Zhang, J. Mechanical properties, intergranular corrosion behavior and microstructure of Zn modified Al-Mg alloys. J. Alloy. Compd. 2014, 617, 925-932. [CrossRef]

27. Xia, S.L.; Ma, M.; Zhang, J.X.; Wang, W.X.; Liu, W.C. Effect of heating rate on the microstructure, texture and tensile properties of continuous cast AA 5083 aluminum alloy. Mater. Sci. Eng. A 2014, 609, 168-176. [CrossRef]

28. García-Bernal, M.A.; Mishra, R.S.; Verma, R.; Hernández-Silva, D. Hot deformation behavior of friction-stir processed strip-cast 5083 aluminum alloys with different Mn contents. Mater. Sci. Eng. A 2012, 534, 186-192. [CrossRef]

29. Kumar, S.; Babu, N.H.; Scamans, G.M.; Fan, Z.; O'Reilly, K.A.Q. Twin Roll Casting of Al-Mg Alloy with High Added Impurity Content. Metall. Mater. Trans. A 2014, 45, 2842-2854. [CrossRef]

30. Liu, W.C.; Morris, J.G. Quantitative Analysis of Texture Evolution in Cold-Rolled, Continuous-Cast AA 5xxx-Series Aluminum Alloys. Metall. Mater. Trans. A 2004, 35, 265-277. [CrossRef]

31. Zhao, Y.M.; Morris, J.G. Comparison of the texture evolution of direct chill and continuous cast AA5052 hot bands during isothermal annealing. Metall. Mater. Trans. A 2005, 36, 2505-2515. [CrossRef]

32. Liu, Y.L.; Hu, Z.Q.; Zhang, Y.; Shi, C.X. The solidification behavior of 8090 AI-Li alloy. Metall. Trans. B 1993, 24, 857-865. [CrossRef]

33. Liu, K.; Cao, X.; Chen, X.-G. Formation and phase selection of iron-rich intermetallics in Al-4.6Cu-0.5Fe cast alloys. Metall. Mater. Trans. A 2013, 44, 682-695. [CrossRef]

34. Mondolfo, L.F. Aluminium Alloys: Structure and Properties; Butterworths \& co.: London, UK, 1976; p. 324.

35. Kattner, U.R.; Burton, B.P. ASM Handbook Volume 3: Alloy Phase Diagrams; ASM International: Geauga County, OH, USA, 1992; pp. 2-44.

36. Mondolfo, L.F. Aluminium Alloys: Structure and Properties; Butterworths \& Co.: London, UK, 1976; p. 529.

37. Liu, Y.L.; Luo, L.; Han, C.; Ou, L.; Wang, J.; Liu, C. Effect of Fe, Si and Cooling Rate on the Formation of Fe- and Mn-rich Intermetallics in Al-5Mg-0.8Mn Alloy. J. Mater. Sci. Technol. 2015. Available online: http://www.sciencedirect.com/science/article/pii/S1005030215001760 (accessed on 19 October 2015). [CrossRef]

(C) 2016 by the authors; licensee MDPI, Basel, Switzerland. This article is an open access article distributed under the terms and conditions of the Creative Commons by Attribution (CC-BY) license (http://creativecommons.org/licenses/by/4.0/). 